\title{
The Effects of Profitability, Leverage, and Liquidity on Financial Distress on Retail Companies Listed on Indonesian Stock Exchange
}

\author{
Neneng Susanti ${ }^{1}$, Ifa Latifa ${ }^{2}$, Denok Sunarsi ${ }^{3}$ \\ ${ }^{1,2}$ Universitas Widyatama \\ ${ }^{3}$ Universitas Pamulang \\ Email: neneng.susanti@widyatama.ac.id
}

(Received: January 10-2020; revised: May 11-2020; published: June 30-2020)

\begin{abstract}
The study aims to find out the influence of profitability variables (Return On Assets), Leverage (Debt To Asset Ratio) and liquidity (Current Ratio) on Financial Distress on retail companies listed on the 20142018 period Indonesian Stock Exchange. The population of this study is the entire company contained on the Indonesian Stock Exchange listed retail company of the period 2014-2018. The research sample consists of 21 companies used by purposive sampling methods and taken that meet with criteria from predetermined research samples. The data analysis method used is panel data regression analysis (Random Effect) with a significance level of 5 percent. Based on the results of the research that has been conducted led to that, simultaneously Profitability, Leverage and Liquidity variables have an effect on Financial Distress. Partially variable Profitability has a significant positive effect on Financial Distress, Leverage variables have a significant positive effect on Financial Distress, and negatively significant negatively influential Liquidity variables on Financial Distress. The magnitude of the influence of Profitability, Leverage, and Liquidity on Financial Distress amounted to 98.87 percent, while the rest amounted to 1.13 percent was affected by other variables outside of research.
\end{abstract}

Keywords: Profitability; leverage; liquidity; financial distress

\section{INTRODUCTION}

The pace of growth of the world's economic conditions is undergoing considerable progress each year, various ways businesspeople do to maintain and develop competitive advantages with their competitors (Horne, J.C. dan Wachowicz, 2007; Mulyanti, 2016). The company's competition of one with the other is getting tighter and tighter, thus causing the costs incurred by the company to also get bigger. Factors that can make the company maintain its business activities continuity also need to be noticed by understanding about business failures, as businesses always have the disadvantage of having difficulty even financial failures (Rengifurwarin et al., 2018).

The company constitutes an organization founded with the goal of earning a huge profit. In addition the company also focused on the company's survival to continue going concern. The assumption of going concern used a business entity in running its efforts. With the existence of a going concern an entity is considered capable of sustaining its efforts in the long run and will not be liquidated in the short term (Prabowo \& Wibowo, 2017). Management capabilities within a company in order to maintain the company's condition to continue going concern will spare the company from the occurrence of financial difficulties (financial distress) which could cause business bankruptcy to be brought to a later date. The initial stage of business bankruptcy that 
46| Jurnal Ilmiah Ilmu Administrasi Publik: Jurnal Pemikiran dan Penelitian Administrasi Publik

Volume 10 Number 1, January- june 2020. Page 45-52

occurs within the company is usually prefixed with the occurrence of financial difficulties (Opler \& Titman, 1994; Outecheva, 2007).

The shift of community shopping style to a signalized electronic trading platform coinfluenced the sales of fast moving consumer goods (FMCG) in modern retail. However, in general the development of modern retail ventures in Indonesia, seen from the magnitude of consumption of FMCG products, during April 2018-April 2019 still grew positive by $1.8 \%$ with modern retail growth of $6.6 \%$. Nevertheless, modern retail businesses will still record growth in Indonesia. (economics.bisnis.com).

Methods for predicting financial distress have been done enough as well as providing different results each of his researches, a wide variety of bankruptcy prediction methods have been developed by some experts, among others the (Miller \& Springate, 1978) and (Zmijewski, 1984) methods. (Huda et al., 2019)) stated that for the Zmijewski model it can be inferred is the best model because it has the lowest error rate than both the altman and springate methods. According to BAPEPAM in (Setiawati, 2017) states that the Zmijewski method combines various financial ratios together, then there exists a ratio of pre-interest and tax to total assets of incomes the best indicator of knowing the occurrence of bankruptcy and providing suitable coefficients to combine variables - independent variables. That would make the proportions that would be judged more valid for predicting financial distress. The following are described financial distress conditions occurring in the retail sector listed in the 2014-2018 period BEI as follows:

Figure 1.

Graph Conditions of Financial Distress Proxyed With Zmijewski on the Retail Sector Listed on Indonesian Stock Exchange Period 2014-2018

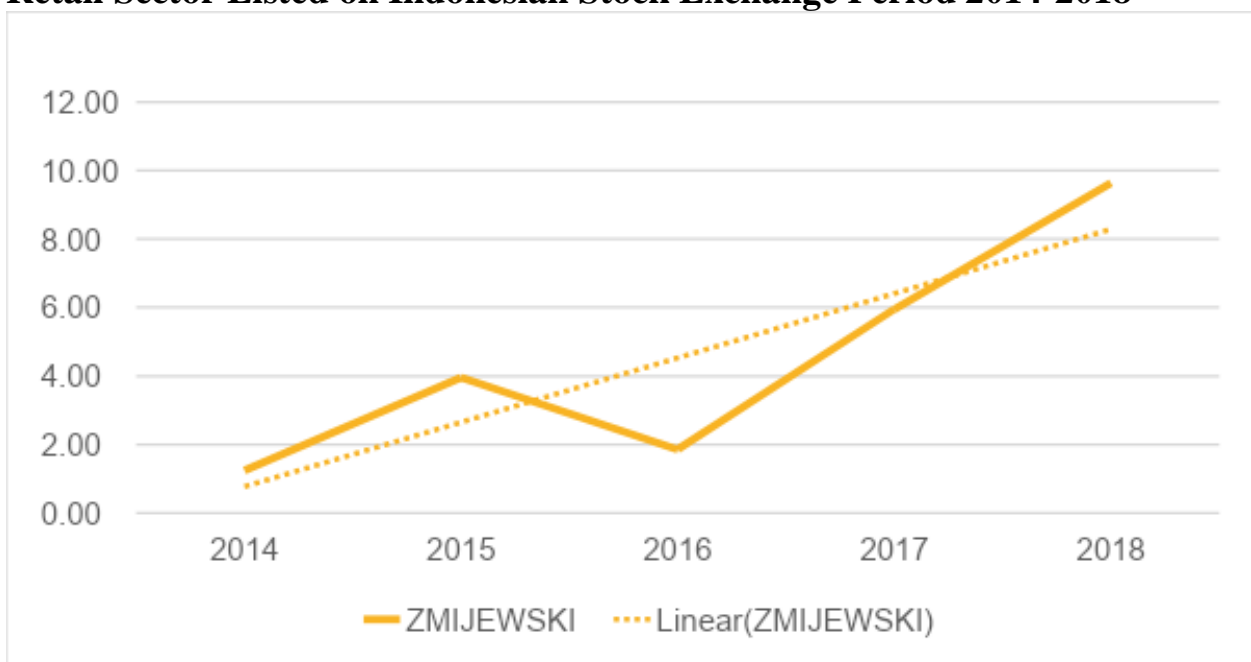

Source : Data Processing Results

From the chart it can be seen that financial distress conditions on the retail sector listed in the 2014-2018 period BEI tend to experience increases. In the period 2014-2015 saw a last increase in the period 2015-2016 in decline and in the period 2016-2018 experienced a fairly significant re-ascension. Based on the calculation of zmijewski the company underwent 
financial distress when the value of zmijewski was more than 0 and it can be seen that the value of zmijewski showed a value of more than 0 meaning the period 2013-2018 on the retail sector company was predicted to be financial distressed. Then, the trendline can be seen that in the 2014-2018 period showed a fairly significant increase in each year.

The swindling conditions of retail businesses in Indonesia are strongly related to financial distress where many retail companies are already in the financial distress zone but can remain to date. One cause of financial distress is the existence of mismanagement, poor financial decisions whereas effective management planning can help delay the decline and failure (Andersen et al., 2013; Saunders \& Cornett, 2014; Wong, 2006)

Profitability is a ratio that measures the ability of a company to generate profits (Anderson et al., 1994; Olalere et al., 2017; Ponsian, 2014). According to (Brigham \& Houston, 2012)) to measure financial performance, the ratio used that is the profitability ratio because this ratio has covered debt ratio, activity ratio as well as liquidity ratio. The profitability ratio consists of ROA (Return On Assets) which is the ratio showing the ability of the entire assets that exist and are used to make Return on Assets (ROA) profits is the result of comparisons between EBIT and total assets, which in the retail company it shows that in Indonesia in recent years there have been several companies that closed their outlets based on the assets it has and ROA are also able to measure the ability of the company to generate profits in the past years projected in the foreseeable future.

The leverage ratio according to (Hery, 2015) represents the ratio used to measure the extent to which the company's assets are financed with debt. That is, the leverage ratio is a ratio used to measure how large the debt burden a company should bear in the order of asset fulfillment. The commonly used leverage ratio on research is debt asset ratio. Debt asset ratio is calculated by the way total debt is divided by total asset, viewed from the development of the retail company that the asset owned is dwindling and total debt is getting higher which can get some companies to close its business outlets.

The liquidity ratio is a ratio that measures the ability of a company to meet its short-term obligations. One of the liquidity ratios is current ratio where it describes the company's ability in paying off short-term liabilities by utilizing its smooth assets. According to (Munawir, 2005) current ratio is a ratio that indicates the safety level (margin of safety) of short-term creditors, or the ability of the company to pay those debts. Current ratio is a comparison of the smooth assets with the smooth debt, whereby an asset within this retail company has increasingly shrinking value and an increasingly high debt that can get some companies to close its business outlets.

\section{METHOD}

According to (sugiyono, 2014) the object of research is an attribute or trait that has certain variations set by researchers to study and then draw conclusions. The research object the author applied according to the one to be researched is financial distress retail companies with Profitability, leverage and liquidity ratios that are proxyed with ROA, DAR and CR on retail companies listed on the Indonesian Stock Exchange (BEI) period 2014-2018. The analysis unit is something to do with the focus studied. Analysis units can be objects, individuals, groups, regions and specific times according to the research focus. The study used a company or organizational analysis unit, namely the retail company listed on the Indonesian Stock Exchange (BEI) period 2014-2018. 
48| Jurnal Ilmiah Ilmu Administrasi Publik: Jurnal Pemikiran dan Penelitian Administrasi Publik

Volume 10 Number 1, January- june 2020. Page 45-52

The population in the study was a company listed on the Indonesian Stock Exchange (BEI) period 2014-2018. The number of populations in this study was 25 companies. Samples in this study used non-probability sampling methods, namely non-random sample retrieval methods with purposive sampling selection techniques

The method of data analysis in this study was panel data regression analysis. Panel data is a composite of cross section data and time series (time series) which are a number of observation variables over a number of categories and collected within a given period of time. This panel data regression test is used to know the relationship between independent variables with dependent variables. Testing will be done through the following stages: classical assumption testing, multiple linear regression analysis, determination coefficient, simultaneous and partial hypothesis testing. The testing was conducted with the help of Eviews 10 software. Multiple liniear regression is used to test the influence of two or more independent variables on a single dependent variable and is generally expressed in the equation as follows:

Adhes $=a+\ldots$ (1) X_1 +_(2) X_2 +_(3) X_3 + $\mu$

The research's liniear aggression uses a panel data regression model with independent variables namely Profitability, Leverage and Liquidity to Financial Distress, whereby such regression models are described through the equation as follows:

$\mathrm{a}+\_1 \mathrm{ROA} \_$it $+\_2 \mathrm{DAR} \_$it $+\_3 \mathrm{CR} \_$it

\section{RESULT AND DISCUSSION}

The liquidity ratio is a ratio that measures the ability of a company to meet its short-term obligations. To be able to fulfill its obligations, then the company must have tools to pay which are smooth assets whose amounts must be far greater than those obligations to be paid by the company. When the company is able to fund and pay off its short-term obligations well then the company's potential to experience financial distress will get smaller. In contrast, if the company is unable to pay off its short-term obligations then the more likely the financial distress is.

Random Effect Model is used as an estimation of panel data leading to the conclusion that independent variables of profitability, leverage, and liquidity jointly affect Financial Distress. Results of regression parameter estimation using the random effect cross-section model approach: 


\section{Table 1.}

\section{Statistic Analysis}

Dependent Variable: FD

Method: Panel Least Squares

Date: 11/11/19 Time: $13: 42$

Sample: 20142018

Periods included: 5

Cross-sections included: 15

Total panel (balanced) observations: 75

\begin{tabular}{lllll}
\hline Variable & Coefficient & Std. Error & t-Statistic & Prob. \\
\hline & 30723. & 231.10 & $i .10621$ & 1000 \\
ROA & 5.086839 & 0.223380 & 22.77215 & 0.0000 \\
DAR & 7.105715 & 0.233332 & 30.45329 & 0.0000 \\
CR & -0.209513 & 0.084672 & -2.474397 & 0.0163 \\
\hline
\end{tabular}

Effects Specification

Cross-section fixed (dummy variables)

\begin{tabular}{llll}
\hline R-squared & 0.988715 & Mean dependent var & -164107.0 \\
Adjusted R-squared & 0.985349 & S.D. dependent var & 169734.4 \\
S.E. of regression & 20545.07 & Akaike info criterion & 22.90419 \\
Sum squared resid & $2.41 \mathrm{E}+10$ & Schwarz criterion & 23.46039 \\
Log likelihood & -840.9072 & Hannan-Quinn criter. & 23.12628 \\
F-statistic & 293.7504 & Durbin-Watson stat & 1.414027 \\
Prob(F-statistic) & 0.000000 & & \\
\hline
\end{tabular}

Source : Data Processing Results

Based on the table there are constant values and regression coefficients, so that can be formed the regression equation as follows:

$\mathrm{Y}=-1130723-5,086839 \mathrm{X} 1-7,105715 \mathrm{X} 2-0.209513 \mathrm{X} 3+\mathrm{e}$

The above equations can be interpreted as follows:

$0=1130723$ meaning if the variable ROA (X1), DAR (X2), CR (X3),), is zero-valued (0), then the variable Financial Distress(Y) will be worth 1130723 units. Or dengen another sense, the line-regression line will cut the $\mathrm{Y}$ axis at point 1130723.

$1=5,086839$ in effect if the variable ROA (X_1) increases by one unit and the other variable is constant, then the variable Financial Distress (Y) will decrease by 5,086839 units. 
50 Jurnal Ilmiah Ilmu Administrasi Publik: Jurnal Pemikiran dan Penelitian Administrasi Publik Volume 1o Number 1, January- june 2020. Page 45-52

$2=7,105715 \mathrm{~s}$ means if the DAR variable (X_2) increases by one unit and the other variable is constant, then the Financial Distress (Y) variable will decrease by 7, 105715 units.

$3=-0.209513 \mathrm{~s}$ mean if the CR variable (X_3) increases by one unit and the other variable is constant, then the Financial Distress (Y) variable will decrease by -0.209513 units.

Based on the value obtained table $F$ count by 293,7504. This value will then be compared to the $\mathrm{F}$ value in the $\mathrm{F}$ distribution table. For $\alpha=5 \%$, df $1=\mathrm{k}=3$, and $\mathrm{df} 2=\mathrm{n}-\mathrm{k}-1=75-3-$ $1=71$ is obtained the $F$ table value of 2,73 . Due to the value $F$ count greater than the value $F$ table $(293,7504>2.82)$, then $\mathrm{H} 0$ is denied and $\mathrm{H} 1$ is received, meaning that $\mathrm{ROA}(\mathrm{X} 1)$, $\mathrm{DAR}(\mathrm{X} 2), \mathrm{CR}(\mathrm{X} 3)$ are jointly as significant influences on Financial Distress(Y).

\section{CONCLUSION}

Affirmative Development of profitability, leverage and liquidity to financial distress on retail companies listed on the 2014-2018 period Indonesian Stock Exchange is as follows:

Affirmative Development of profitability, leverage and liquidity to financial distress in Indonesian Stock Exchange listed retail companies of 2014-2018 period is fluctuating. Profitability is experiencing an increase. Whereas leverage and liquidity tend to decrease. Influence of profitability, leverage and liquidity to financial distress on retail companies listed on the 2014-2018 period Indonesian Stock Exchange is as follows:

Profitability, leverage and liquidity were joinly significant influential to financial distress on retail companies listed on the 2014-2018 period Indonesian Stock Exchange. Profitability was partially influential significant on financial distress in Indonesian Stock Exchange listed retail companies of 2014-2018 period, leverage partially influential significant on financial distress in Indonesian Stock Exchange listed retail companies of 2014-2018 period, and liquidity partially influential significant on financial distress on retail companies listed on Indonesian Stock Exchange of 2014-2018 period.

\section{REFERENCES}

Andersen, T. G., Bollerslev, T., Christoffersen, P. F., \& Diebold, F. X. (2013). Financial Risk Measurement for Financial Risk Management. In Handbook of the Economics of Finance. https://doi.org/10.1016/B978-0-44-459406-8.00017-2

Anderson, E. W., Fornell, C., \& Lehmann, D. R. (1994). Customer Satisfaction, Market Share, and Profitability: Findings from Sweden. Journal of Marketing. https://doi.org/10.2307/1252310

Brigham, E. F., \& Houston, J. F. (2012). Fundamentals of Financial Management. Cengage Learning.

Hery. (2015). Analisis Laporan Keuangan. CAPS.

Horne, J.C. dan Wachowicz, J. M. (2007). Prinsip-Prinsip Manajemen Keuangan. In PrinsipPrinsip Manajemen Keuangan. https://doi.org/10.4324/9781315641348

Huda, E. N., Paramita, P. D., \& Amboningtyas, D. (2019). Analisis Financial Distress dengan 
Menggunakan Model Altman, Springate dan Zmijewski pada Perusahaan Retail yang Terdaftar di BEI Tahun 2013-2017. Journal of Management, 5(5).

Miller, R. D., \& Springate, D. J. (1978). The Relationship of Strategy, Structure and Management Processes. Academy of Management Proceedings, 1978(1), 121-125.

Mulyanti, D. (2016). Manajemen Keuangan Perusahaan. Jurnal Ilmiah Akuntansi.

Munawir. (2005). Analisis Laporan Keuangan. Liberty.

Olalere, O. E., Bin Omar, W. A., \& Kamil, S. (2017). Bank Specific and Macroeconomic Determinants of Commercial Bank Profitability: Empirical Evidence from Nigeria. International Journal of Finance \& Banking Studies (2147-4486). https://doi.org/10.20525/ijfbs.v6i1.627

Opler, T. C., \& Titman, S. (1994). Financial Distress and Corporate Performance. The Journal of Finance. https://doi.org/10.2307/2329214

Outecheva, N. (2007). Corporate Financial Distress : An Empirical Analysis of Distress Risk. Doctoral Dissertation, University of St. Gallen.

Ponsian, N. (2014). The Effect of Working Capital Management on Profitability. International Journal of Economics, Finance and Management Sciences. https://doi.org/10.11648/j.ijefm.20140206.17

Prabowo, A., \& Wibowo, A. (2017). Pengaruh Persepsi Harga, Persepsi Kualitas Produk, dan Citra Merek terhadap Keputusan Pembelian Sepeda Motor Yamaha Vixion (Studi: Pengguna Sepeda Motor Yamaha Vixion Dicondongcatur). STIE Widya Wiwaha.

Rengifurwarin, Z. A., Akib, H., \& Salam, R. (2018). Snapshot of public service quality in the center for integrated business service (CIBS), cooperative micro small and medium enterprises (CMSME), Maluku Province, Indonesia. Journal of Entrepreneurship Education.

Saunders, A., \& Cornett, M. M. (2014). Financial Institutions Management. In McGraw-Hill Education.

Setiawati, M. H. (2017). Analisis Metode Altman Z-Score, Springate, dan Zmijewski untuk Memprediksi Financial Distress pada Perusahaan Food and Beverage yang Terdaftar di Bursa Efek Indonesia (BEI) periode 2011-2015.

sugiyono. (2014). Metode penelitian. Metode Penelitian.

Wong, K. L. (2006). Financial management. In Professional Housing Management Practices in Hong Kong. https://doi.org/10.5005/jp/books/10677_12

Zmijewski, M. E. (1984). Methodological issues related to the estimation of financial distress prediction models. Journal of Accounting Research, 59-82. 
52 Jurnal Ilmiah Ilmu Administrasi Publik: Jurnal Pemikiran dan Penelitian Administrasi Publik Volume io Number 1, January- june 2020. Page 45-52 